\title{
Rhizobium fabae sp. nov., a bacterium that nodulates Vicia faba
}

\author{
Chang Fu Tian, ${ }^{1}$ En Tao Wang, ${ }^{1,2}$ Li Juan Wu, ${ }^{1}$ Tian Xu Han, ${ }^{1}$ \\ Wen Feng Chen, ${ }^{1}$ Chun Tao Gu, ${ }^{1}$ Jin Gang Gu${ }^{3}$ and Wen Xin Chen ${ }^{1}$ \\ ${ }^{1}$ Key Laboratory of Agro-Microbial Resource and Application, Ministry of Agriculture/College of \\ Biological Sciences, China Agricultural University, 100094 Beijing, PR China \\ ${ }^{2}$ Departamento de Microbiología, Escuela Nacional de Ciencias Biológicas, Instituto Politécnico \\ Nacional, 11340 México D. F., Mexico \\ ${ }^{3}$ Institute of Agricultural Resources and Regional Planning of Chinese Academy of Agricultural \\ Sciences, 100081 Beijing, PR China
}

Correspondence Wen Xin Chen wxchencau@yahoo.com.cn
Six strains were isolated from root nodules of Vicia faba grown in Nanchang, Yifeng, Taihu, Huaibei, Bengbu and Lujiang, in the middle and lower reaches of the Yangtze River. According to phylogenetic analyses of $16 \mathrm{~S}$ rRNA gene, atp $D$ and $\operatorname{rec} A$ sequences, these strains belong to the genus Rhizobium, with Rhizobium etli and Rhizobium leguminosarum as the closest related species. CCBAU $33202^{\top}$, a representative of these novel isolates, showed sequence similarity to its closest relatives $R$. et/i CFN $42^{\top}$ and $R$. leguminosarum USDA $2370^{\top}$ of 99.5 and $99.1 \%$ for the $16 \mathrm{~S}$ rRNA gene, 91.9 and $91.9 \%$ for atp $D$ and 90.3 and $93.2 \%$ for recA. The strains from this study could also be differentiated from $R$. etli CFN $42^{\top}$ and $R$. leguminosarum USDA 2370 by 16 S-IGS RFLP and SDS-PAGE of whole-cell proteins, fatty acid profiles and several phenotypic characteristics. DNA-DNA hybridization yielded relatedness of 19 and $14-43 \%$, respectively, with $R$. etli CFN $42^{\top}$ and strains representing different biovars of $R$. leguminosarum. All data obtained in this study showed that these $V$. faba isolates belong to a novel species, for which the name Rhizobium fabae sp. nov. is proposed. The type strain, CCBAU $33202^{\top}$ (=LMG $23997^{\top}=\mathrm{JCM} 14381^{\top}$ ), was isolated from Nanchang.
It is well known that Vicia faba and other species of Vicia, Pisum, Lathyrus and Lens form nodules with Rhizobium leguminosarum bv. viciae, one of the three biovars of $R$. leguminosarum (Jordan 1984). Earlier studies revealed that rhizobia isolated from nodules of $V$. faba in different geographical locations were diverse in their chromosomal background and plasmid content, and rhizobial strains of $V$. faba were distinguishable from rhizobial strains of Pisum sativum, especially in the nodulation genotypes (van Berkum et al., 1995; Laguerre et al., 2003; Young et al., 2003; Mutch et al., 2003; Mutch \& Young, 2004). However, no species other than Rhizobium leguminosarum bv. viciae has been reported to nodulate $V$. faba. In our previous

The GenBank/EMBL/DDBJ accession numbers for the recA and atpD sequences of strains CCBAU 23122, CCBAU 23123, CCBAU 23127, CCBAU 23132, CCBAU 33201 and CCBAU $33202^{\top}$ are respectively EF579936-EF579941 (recA) and EF579924-EF579929 (atpD). Those for the nodD sequences of strains CCBAU $33202^{\top}$ and CCBAU 23123 are EU430078 and EU430079.

Neighbour-joining trees based on $\operatorname{rec} A$, atp $D$ and nodD sequences and dendrograms based on 16S-IGS RFLP and whole-cell protein SDSPAGE profiles are available as supplementary material with the online version of this paper. study, wide diversity was revealed amongst rhizobia associated with $V$. faba in Chinese fields (Tian et al., 2007). Six strains isolated from six sites in the middle and lower reaches of the Yangtze River formed a distinct group belonging to Rhizobium based upon analysis of BOX-A1R PCR, amplified fragment length polymorphism analysis, amplified 16S rDNA restriction analysis (ARDRA), 16S rRNA gene phylogeny and DNA-DNA hybridization (Tian et al., 2007). In the present study, a polyphasic approach was used to clarify the taxonomic affiliation of this Rhizobium group.

Strains CCBAU $33202^{\mathrm{T}}$ and CCBAU 33201, isolated from Nanchang and Yifeng in Jiangxi province, and CCBAU 23123, CCBAU 23122, CCBAU 23127 and CCBAU 23132, isolated from Taihu, Huaibei, Bengbu and Lujiang in Anhui province, all isolated from $V$. faba, were used in this study. Standard procedures and YMA medium (Vincent, 1970) were used to isolate and cultivate the strains. DNA samples were prepared as described by Terefework et al. (2001).

Previously, these six strains have been grouped in the same ARDRA type, and phylogenetic analysis of $16 \mathrm{~S}$ rRNA gene 
sequences of CCBAU $33202^{\mathrm{T}}$ and CCBAU 23132 showed that they belong to the genus Rhizobium (Tian et al., 2007). According to the $16 \mathrm{~S}$ rRNA gene sequence analysis, the closest relative of CCBAU $33202^{\mathrm{T}}$ is Rhizobium etli CFN $42^{\mathrm{T}}$ ( $99.5 \%$ similarity), followed by R. leguminosarum bv. trifolii T24 (99.3\%), R. leguminosarum bv. viciae USDA $2370^{\mathrm{T}}(99.1 \%)$, R. leguminosarum bv. phaseoli USDA 2671 (99.1\%), Rhizobium rhizogenes IAM $13570^{\mathrm{T}}$ (98.1\%), Rhizobium lusitanum $\mathrm{P} 1-7^{\mathrm{T}}$ (98.0\%), Rhizobium tropici type B CIAT $899^{\mathrm{T}}(97.5 \%)$ and $R$. tropici type A LMG 9517 $(96.8 \%)$.

In order to confirm the phylogenetic position of the six new isolates, in addition to the 16S rRNA gene sequence, the core housekeeping genes $a t p D$ and $r e c A$ were sequenced and their phylogenies were compared with that of the $16 \mathrm{~S}$ rRNA gene. The two housekeeping genes are unlinked and provide independent genealogies from which to infer a species tree (Nichols, 2001; Rosenberg, 2002; Vinuesa et al., 2005). The methods and primers atpD273F (5'-SCTGGGSCGYATCMTGAACGT-3') and atpD771R (5'-GCCGACACTTCCGAACCNGCCTG-3') (Gaunt et al., 2001) for atpD and recA63F (5'-ATCGAGCGGTCGTTCGGCAAGGG-3') and recA555R (5'-CGRATCTGGTTGATGAAGATCACCAT-3') for recA described by Gaunt et al. (2001) were used to amplify the corresponding genes. The PCR products were purified and sequenced directly. CLUSTAL $\mathrm{W}$ (Jeanmougin et al., 1998; Thompson et al., 1994) integrated in MEGA3.1 (Kumar et al., 2004) and BioEdit (Hall, 1999) were used to align and edit the acquired sequences and the related sequences obtained from GenBank. Phylogenetic trees were then reconstructed by the neighbour-joining method with 1000 bootstrap replications using MEGA3.1. As shown in Supplementary Figs S1 and S2, available in IJSEM Online, the results obtained further confirm the distinct phylogenetic position of these test strains within the group of $R$. leguminosarum-R. etli. Sequence similarity among the strains isolated from $V$. faba was above $99.8 \%$ for atpD and more than $97.9 \%$ for recA. The similarity between CCBAU $33202^{\mathrm{T}}$ and $R$. etli CFN $42^{\mathrm{T}}$ and $R$. leguminosarum USDA $2370^{\mathrm{T}}$ was $91.9 \%$ for both strains for atpD and respectively 90.3 and $93.2 \%$ for recA. These values are similar to those found between other closely related Rhizobium species, such as $94.1,92.3$ and $91.8 \%$ for atpD and 91.9, 92.0 and $90.6 \%$ for recA, respectively, between $R$. lusitanum $\mathrm{P} 1-7^{\mathrm{T}}$ and $R$. rhizogenes IAM $13570^{\mathrm{T}}, R$. tropici A CFN 299 and $R$. tropici B CIAT $899^{\mathrm{T}}$ (Valverde et al., 2006). These sequence similarities with respect to $R$. etli and $R$. leguminosarum suggest that the strains isolated in this study may belong to a novel species.

The $\mathrm{G}+\mathrm{C}$ content of the novel strains was $61.5-61.9 \mathrm{~mol} \%$ (Tian et al., 2007), within the range reported for the genus Rhizobium (Jordan, 1984). DNA-DNA reassociation analysis was carried out as described by De Ley et al. (1970). The DNA-DNA relatedness of strain CCBAU $33202^{\mathrm{T}}$ with the other five test strains was $\geqslant 73 \%$, and strain CCBAU $33202^{\mathrm{T}}$ showed 19 and $14-43 \%$ relatedness, respectively, with $R$. etli CFN $42^{\mathrm{T}}$ and strains of the three biovars of $R$. leguminosarum, including the type strain, USDA $2370^{\mathrm{T}}$ (Supplementary Table S1). These results indicate that the six strains from this study do not belong to these recognized species when a value of $70 \%$ or higher DNADNA relatedness for rhizobial species definition was considered (Graham et al., 1991).

In addition to 16S rRNA gene and housekeeping gene analyses and DNA-DNA reassociation, DNA profiling methods that discriminate at the subspecific level also show great promise in the definition of bacterial species (Stackebrandt et al., 2002). In this study, the 16S-IGS region was amplified as described by Rasolomampianina et al. (2005) and the PCR products were digested with DdeI, HaeIII and MspI. A UPGMA dendrogram of 16S-IGS RFLP profiles was obtained with the same method described previously for ARDRA (Tian et al., 2007). Similarities of more than $93.2 \%$ among the $V$. faba isolates and less than $72.8 \%$ between the test strains and reference strains for defined Rhizobium species were observed in the 16S-IGS RFLP UPGMA dendrogram (based on the Dice correlation similarity coefficient) (Supplementary Fig. S3). Moreover, whole-cell protein SDS-PAGE, a subspecific discriminating method at the protein level, was performed to analyse these novel strains and related Rhizobium species with methods described previously (Tan et al., 1997). Normalized densitometric traces of the electrophoretic protein patterns were grouped with Pearson's correlation coefficient and the UPGMA method integrated in the GelCompar software package. The test strains grouped at a similarity of $83 \%$ and clustered with other Rhizobium strains at a similarity of $29 \%$ (Supplementary Fig. S4).

Strains CCBAU $33202^{\mathrm{T}}$ and CCBAU 23123, representing the nodC-nodD RFLP symbiotic genotypes $B$ and $M$ identified previously in the novel strains (Tian et al., 2007), were chosen for nodD sequence analysis with the same procedure described above for housekeeping gene sequences. The nodD primers used herein were the same as those in our earlier study (Tian et al., 2007). In the phylogenetic tree (Supplementary Fig. S5), the novel strains were grouped with $R$. leguminosarum bv. viciae strains nodulating various legume hosts, such as Vicia sativa, V. cracca, V. hirsuta, V. faba, Lathyrus aphaca, L. nissolia, L. pratensis and Pisum sativum. The nodD phylogeny was correlated with the host range of the test strains, since all these novel strains formed effective nodules on $V$. faba (Tian et al., 2007) and CCBAU $33202^{\mathrm{T}}$ and CCBAU 23123 could form effective pink nodules on Pisum sativum and Lathyrus species and did not nodulate Phaseolus vulgaris, Trifolium, Glycine max or Medicago sativa. In short, nodulation gene analysis and nodulation ability tests demonstrated that these novel strains have similar symbiotic characteristics to $V$. faba isolates identified as $R$. leguminosarum bv. viciae (Jordan, 1984).

It has been found that similarities derived from fatty acid analysis are in broad agreement with 16S rRNA gene sequence similarities and appear to distinguish accurately between most rhizobial species (Tighe et al., 2000). In the 
genus Rhizobium, $R$. etli and $R$. leguminosarum are discriminated less clearly from each other and form a subcluster with similar fatty acid profiles (Tighe et al., 2000). Using a previously described method (Graham et al., 1995; Jarvis \& Tighe, 1994; Tighe et al., 2000), fatty acid profiles of strains CCBAU $33202^{\mathrm{T}}$ and CCBAU 23123 from $V$. faba were determined in this study and were compared with those of the related Rhizobium species (Table 1; Tighe et al., 2000). Major fatty acids found in Rhizobium, such as $16: 0,18: 0,19: 0$ cyclo $\omega 8 c$, summed feature 3 and summed feature 7 , were detected in the test strains, and the novel strains could be differentiated from members of other rhizobial genera. Within the genus Rhizobium, the $V$. faba strains could also be differentiated from related species (Table 1). For example, they have 15:0 2-OH, 18:0 3-OH and $18: 1 \omega 9 c$, but not iso-15:0 3-OH, 18:1 2-OH or $20: 3 \omega 6,9,12 c$, and they have relatively larger amounts of summed feature 7 and smaller amounts of 19:0 cyclo $\omega 8 c$.

Phenotypic characteristics were tested for the novel strains and reference strains of the closest related species of genus Rhizobium using the methods of Gao et al. (1994). Fortytwo different carbon sources and 15 amino acids as sole nitrogen sources were tested. Antibiotic resistance was investigated with ampicillin, bacitracin, chloramphenicol, erythromycin, kanamycin, neomycin and streptomycin at concentrations of $300,100,50$ and $5 \mu \mathrm{g} \mathrm{ml}^{-1}$ using YMA medium. The temperature range for growth was determined by incubating cultures in YMA plates between 4 and $37^{\circ} \mathrm{C}$. The $\mathrm{pH}$ range was measured in YMA or TY

Table 1. Major fatty acids of the novel strains (Rhizobium fabae sp. nov.) and related Rhizobium species

Strains: $1, R$. galegae ( $n=19) ; 2, R$. giardinii $(n=20) ; 3$, . gallicum $(n=17) ; 4, R$. hainanense $(n=13) ; 5, R$. tropici $(n=18) ; 6, R$. etli $(n=30) ; 7, R$. leguminosarum $(n=28) ; 8, R$. fabae CCBAU $33202^{\mathrm{T}} ; 9$, $R$. fabae CCBAU 23123 . Values are percentages of total fatty acids; values below $0.1 \%$ are not shown. Data for reference species were taken from Tighe et al. (2000) and are means for the number of strains shown. ECL, Equivalent chain length.

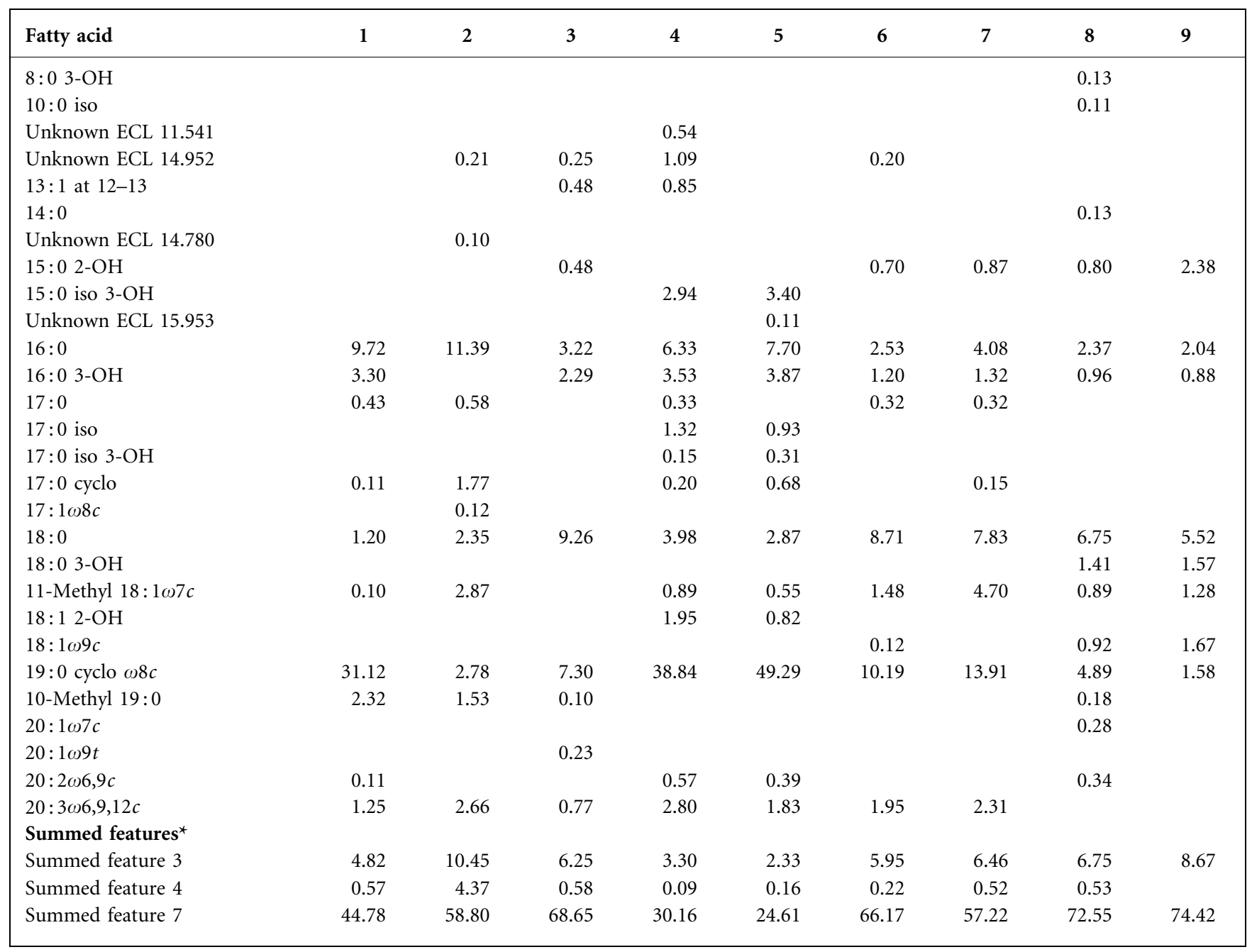

*Summed features represent groups of two or more fatty acids that could not be separated by the MIDI System. Summed feature 3 contains one or more of 12:0 (aldehyde?), unknown ECL 10.928, 16:1 iso I and/or 14:0 3-OH; summed feature 4 contains 15:0 iso 2-OH and/or 16:1 107 ; summed feature 7 contains one or more of $18: 1 \omega 7 c / \omega 9 t / \omega 12 t$ and/or $18: 1 \omega 7 c / \omega 9 c / \omega 12 t$. 
medium with a final $\mathrm{pH}$ between 4.0 and 11.2. Salt tolerance was studied in YMA medium containing 0-4\% (w/v) NaCl. Aerobic and anaerobic growth in semisolid YMA medium, indole production, reactions in the methyl red and Voges-Proskauer tests and hydrolysis of starch, gelatin, DNA and Tween 80 were also determined. The six novel strains from this study had the same characteristics in most cases except that CCBAU 23123 could grow at $\mathrm{pH}$ 9.0-9.4 and resist $300 \mu \mathrm{g}$ bacitracin $\mathrm{ml}^{-1}$. Strains CCBAU $33202^{\mathrm{T}}$, CCBAU 23123 and CCBAU 23127 were further compared with $R$. etli CFN $42^{\mathrm{T}}$ and R. leguminosarum USDA $2370^{\mathrm{T}}$ in the following properties: activities of catalase, urease, oxidase and nitrate reductase, reduction of litmus milk, Nile blue and methylene blue and litmus milk acid production, acid coagulation, alkali production and peptonization. Strains CCBAU $33202^{\mathrm{T}}$, CCBAU 23123 and CCBAU 23127 had the same characteristics in these tests. The novel strains could be differentiated from their closest relatives, $R$. etli CFN $42^{\mathrm{T}}$ and $R$. leguminosarum USDA $2370^{\mathrm{T}}$, by several phenotypic characteristics (Table 2).

The novel strains that nodulate $V$. faba in the middle and lower reaches of the Yangtze River in China can therefore be differentiated genotypically and phenotypically from previously described species, and we propose the name Rhizobium fabae sp. nov. to accommodate them.

Table 2. Distinctive features of $R$. fabae sp. nov. and its closest relatives

Strains: 1, R. fabae sp. nov. (six strains were investigated for utilization of carbon sources and antibiotic resistance; three strains were investigated for reduction of dyes and litmus acid coagulation); 2, R. etli CFN $42^{\mathrm{T}}$; 3, R. leguminosarum USDA $2370^{\mathrm{T}}$. Data were obtained in this study unless indicated.

\begin{tabular}{|lccc|}
\hline Feature & $\mathbf{1}$ & $\mathbf{2}$ & $\mathbf{3}$ \\
\hline Utilization as sole carbon source of: & & & \\
$\quad$ Calcium gluconate & + & - & - \\
Calcium malonate & - & $-{ }^{a \star}$ & $+^{a}$ \\
Erythritol & - & $-{ }^{b}$ & $+^{b}$ \\
Inulin & - & - & + \\
Sodium pyruvate & + & - & + \\
Sodium D-gluconate & - & - & + \\
Sodium hippurate & - & - & + \\
Sodium tartrate & - & - & + \\
L-Arginine & + & + & - \\
L-Aspartic acid & + & - & + \\
Reduction of: & & & \\
Nile blue & - & + & $-{ }^{a}$ \\
Methylene blue & + & - & $-{ }^{a}$ \\
Litmus acid coagulation & + & + & $-{ }^{a}$ \\
Antibiotic resistance $\left(\mu \mathrm{g} \mathrm{ml}{ }^{-1}\right)$ & & & \\
Streptomycin $(300)$ & - & $+^{a}$ & $-{ }^{a}$ \\
Ampicillin $(50)$ & - & $+^{a}$ & $+^{a}$ \\
\hline
\end{tabular}

${ }^{\star}$ Data from: $a$, Wei et al. (2003); b, Amarger et al. (1997) and Chen et al. (1997) (confirmed in this study).

\section{Description of Rhizobium fabae sp. nov.}

Rhizobium fabae [fa'bae. L. gen. n. fabae of a bean, referring to the isolation of the first strains from broad bean or fava bean (Vicia faba)].

Cells are Gram-negative, motile, aerobic, non-sporeforming rods, $0.5-0.7 \mu \mathrm{m}$ wide by $2.0-2.5 \mu \mathrm{m}$ long. Colonies are circular, convex and pearl white on YMA at $28{ }^{\circ} \mathrm{C}$ and $\mathrm{pH} 7$, the optimal growth temperature and $\mathrm{pH}$. Strains grow at $10-37^{\circ} \mathrm{C}$ and $\mathrm{pH} 5-8(\mathrm{pH} 5-9.4$ for CCBAU 23123) and grow weakly up to $2 \%(w / v) ~ N a C l$. Tests for catalase, urease, oxidase and litmus milk acid production, acid coagulation and peptonization are positive. Tests negative for nitrate reductase, indole and $\mathrm{H}_{2} \mathrm{~S}$ production and hydrolysis of starch, gelatin, DNA and Tween 80. Reduces litmus milk and methylene blue, but methyl red and Voges-Proskauer reactions are negative. Utilizes D-amygdalin, D-arabinose, calcium gluconate, Dfructose, D-galactose, D-glucose, inositol, lactose, sodium malate, maltose, D-mannose, turanose, sodium pyruvate, raffinose, L-rhamnose, salicin, sodium acetate, sodium citrate, sodium succinate, sucrose, trehalose, D-xylose, Larginine, L-aspartic acid and L-proline as carbon sources. Grows on DL-alanine, L-arginine, L-aspartic acid, L-cystine, L-glutamic acid, hypoxanthine, L-lysine, L-phenylalanine, glycine and L-hydroxyproline and grows weakly on Dglutamic acid, L-isoleucine, L-valine and L-threonine as nitrogen sources. Test strains are resistant to $\left(\mu \mathrm{g} \mathrm{ml}^{-1}\right)$ ampicillin (5), chloramphenicol (5), kanamycin (5), neomycin (5), streptomycin (100), bacitracin (100) and erythromycin (5). The major fatty acids of Rhizobium species, $16: 0,18: 0,19: 0$ cyclo $\omega 8 c$ and summed features 3 and 7, are detected; 15:0 2-OH, 18:1 $1 \omega 9 c, 11$-methyl $18: 1 \omega 7 c$ and $18: 03-\mathrm{OH}$ are also found. The $\mathrm{G}+\mathrm{C}$ content of the type strain is $61.9 \mathrm{~mol} \%$.

The type strain, CCBAU $33202^{\mathrm{T}}$ (=LMG $23997^{\mathrm{T}}=\mathrm{JCM}$ $14381^{\mathrm{T}}$ ), was isolated from effective nodules of Vicia faba in Nanchang, Jiangxi province, China. Strain CCBAU 33201, isolated from Yifeng in Jiangxi province, and CCBAU 23123 (=LMG $23998=J C M$ 14382), CCBAU 23122, CCBAU 23127 and CCBAU 23132, isolated from Taihu, Huaibei, Bengbu and Lujiang in Anhui province, all isolated from $V$. $f a b a$, are reference strains.

\section{Acknowledgements}

We thank Dr Hai Sheng Wang and Yu Shi (Institute of Agricultural Resources and Regional Planning of Chinese Academy of Agricultural Sciences) for their help in fatty acid analysis. This work was supported by the Foundation of the State Key Basic Research and Development Plan of China (grant 2006CB100206) and by the National Project for Basic S\&T Platform Construction (grant 2005DKA21201-10).

\section{References}

Amarger, N., Macheret, V. \& Laguerre, G. (1997). Rhizobium gallicum sp. nov. and Rhizobium giardinii sp. nov., from Phaseolus vulgaris nodules. Int J Syst Bacteriol 47, 996-1006. 
Chen, W. X., Tan, Z. Y., Gao, J. L., Li, Y. \& Wang, E. T. (1997). Rhizobium hainanense sp. nov., isolated from tropical legumes. Int $J$ Syst Bacteriol 47, 870-873.

De Ley, J., Cattoir, H. \& Reynaerts, A. (1970). The quantitative measurement of DNA hybridization from renaturation rates. Eur $J$ Biochem 12, 133-142.

Gao, J. L., Sun, J. G., Li, Y., Wang, E. T. \& Chen, W. X. (1994). Numerical taxonomy and DNA relatedness of tropical rhizobia isolated from Hainan Province, China. Int J Syst Bacteriol 44, 151158.

Gaunt, M. W., Turner, S. L., Rigottier-Gois, L., Lloyd-Macgilp, S. A. \& Young, J. P. W. (2001). Phylogenies of atpD and recA support the small subunit rRNA-based classification of rhizobia. Int J Syst Evol Microbiol 51, 2037-2048.

Graham, P. H., Sadowsky, M. J., Keyser, H. H., Barnet, Y. M., Bradley, R. S., Cooper, J. E., De Ley, J., Jarvis, B. D. W., Roslycky, E. B. \& other authors (1991). Proposed minimal standards for the description of new genera and species of root- and stem-nodulating bacteria. Int $J$ Syst Bacteriol 41, 582-587.

Graham, P. H., Sadowsky, M. J., Tighe, S. W., Thompson, J. A., Date, R. A., Howieson, J. G. \& Thomas, R. (1995). Differences among strains of Bradyrhizobium in fatty acid-methyl ester analysis. Can J Microbiol 41, 1038-1042.

Hall, T. A. (1999). BioEdit: a user-friendly biological sequence alignment editor and analysis program for Windows 95/98/NT. Nucleic Acids Symp Ser 41, 95-98.

Jarvis, B. D. W. \& Tighe, S. W. (1994). Rapid identification of Rhizobium species based on cellular fatty acid analysis. Plant Soil 161, 31-41.

Jeanmougin, F., Thompson, J. D., Gouy, M., Higgins, D. G. \& Gibson, T. J. (1998). Multiple sequence alignment with CLUSTAL_X. Trends Biochem Sci 23, 403-405.

Jordan, D. C. (1984). Genus I. Rhizobium Frank 1889, $338^{\mathrm{AL}}$. In Bergey's Manual of Systematic Bacteriology, vol. 1, pp. 235-242. Edited by N. R. Krieg \& J. G. Holt. Baltimore: Williams \& Wilkins.

Kumar, S., Tamura, K. \& Nei, M. (2004). MEGA3: integrated software for molecular evolutionary genetics analysis and sequence alignment. Brief Bioinform 5, 150-163.

Laguerre, G., Louvrier, P., Allard, M. R. \& Amarger, N. (2003). Compatibility of rhizobial genotypes within natural populations of Rhizobium leguminosarum biovar viciae for nodulation of host legumes. Appl Environ Microbiol 69, 2276-2283.

Mutch, L. A. \& Young, J. P. W. (2004). Diversity and specificity of Rhizobium leguminosarum biovar viciae on wild and cultivated legumes. Mol Ecol 13, 2435-2444.

Mutch, L. A., Tamimi, S. M. \& Young, J. P. W. (2003). Genotypic characterisation of rhizobia nodulating Vicia faba from the soils of Jordan: a comparison with UK isolates. Soil Biol Biochem 35, 709-714.

Nichols, R. (2001). Gene trees and species trees are not the same. Trends Ecol Evol 16, 358-364.

Rasolomampianina, R., Bailly, X., Fetiarison, R., Rabevohitra, R., Béna, G., Ramaroson, L., Raherimandimby, M., Moulin, L., De
Lajudie, P. \& other authors (2005). Nitrogen-fixing nodules from rose wood legume trees (Dalbergia spp.) endemic to Madagascar host seven different genera belonging to $\alpha$ - and $\beta$-Proteobacteria. Mol Ecol 14, 4135-4146.

Rosenberg, N. A. (2002). The probability of topological concordance of gene trees and species trees. Theor Popul Biol 61, 225-247.

Stackebrandt, E., Frederiksen, W., Garrity, G. M., Grimont, P. A., Kämpfer, P., Maiden, M. C., Nesme, X., Rosselló-Mora, R., Swings, J. \& other authors (2002). Report of the ad hoc committee for the reevaluation of the species definition in bacteriology. Int J Syst Evol Microbiol 52, 1043-1047.

Tan, Z. Y., Wang, E. T., Gao, J. L., Martinez-Romero, E. \& Chen, W. X. (1997). Phylogenetic and genetic relationships of Mesorhizobium tianshanese and related rhizobia. Int J Syst Bacteriol 47, 874-879.

Terefework, Z., Kaijalainen, S. \& Lindström, K. (2001). AFLP fingerprinting as a tool to study the genetic diversity of Rhizobium galegae isolated from Galega orientalis and Galega officinalis. J Biotechnol 91, 169-180.

Thompson, J. D., Higgins, D. G. \& Gibson, T. J. (1994). ClustAL W: improving the sensitivity of progressive multiple sequence alignment through sequence weighting, position-specific gap penalties and weight matrix choice. Nucleic Acids Res 22, 4673-4680.

Tian, C. F., Wang, E. T., Han, T. X., Sui, X. H. \& Chen, W. X. (2007). Genetic diversity of rhizobia associated with Vicia faba in three ecological regions of China. Arch Microbiol 188, 273-282.

Tighe, S. W., de Lajudie, P., Dipietro, K., Lindström, K., Nick, G. \& Jarvis, B. D. W. (2000). Analysis of cellular fatty acids and phenotypic relationships of Agrobacterium, Bradyrhizobium, Mesorhizobium, Rhizobium and Sinorhizobium species using the Sherlock Microbial Identification System. Int J Syst Evol Microbiol 50, 787-801.

Valverde, A., Igual, J. M., Peix, A., Cervantes, E. \& Velázquez, E. (2006). Rhizobium lusitanum sp. nov., a bacterium that nodulates Phaseolus vulgaris. Int J Syst Evol Microbiol 56, 2631-2637.

van Berkum, P., Beyene, D., Vera, F. T. \& Keyser, H. H. (1995). Variability among Rhizobium strains originating from nodules of Vicia faba. Appl Environ Microbiol 61, 2649-2653.

Vincent, J. M. (1970). A Manual for the Practical Study of the Rootnodule Bacteria. Oxford: Blackwell Scientific.

Vinuesa, P., Silva, C., Werner, D. \& Martinez-Romero, E. (2005). Population genetics and phylogenetic inference in bacterial molecular systematics: the roles of migration and recombination in Bradyrhizobium species cohesion and delineation. Mol Phylogenet Evol 34, 29-54.

Wei, G. H., Tan, Z. Y., Zhu, M. E., Wang, E. T., Han, S. Z. \& Chen, W. X. (2003). Characterization of rhizobia isolated from legume species within the genera Astragalus and Lespedeza grown in the Loess Plateau of China and description of Rhizobium loessense sp. nov. Int J Syst Evol Microbiol 53, 1575-1583.

Young, J. P. W., Mutch, L. A., Ashford, D. A., Zézé, A. \& Mutch, K. E. (2003). The molecular evolution of host specificity in the rhizobiumlegume symbiosis. In Genes in the Environment, pp. 245-257. Edited by R. Hails, H. C. J. Godfray \& J. Beringer. Oxford: Blackwell Science. 